\title{
細胞融合による優良ワイン酵母の育種 ${ }^{\dagger}$
}

\author{
清 水 健 一 \\ (サントネージュロイン株式会社研究所)
}

\section{はじめに}

近年，原料であるブドウ果汁の質ばかりではなく，発 䤏に用いるワイン酵母菌株も，ワインの品質の重要な決 定因子であるとの認識が，ワイン生産者の間に定着する につれて、ワイン酵母に関する遗伝学的研究，育種研究 が，遅ればせながら，徐及に行かれるよらになってき た.ワイン醉母育種目的は多岐にわたるが，大別して 次の3つ飞分類される。

（1）ワインの品質向上：キラー性，低温発酵性の付 与，硫化水素，高級アルニール生成の抑制，エステルな どの香気成分生成の增強, アントシアニンの吸着, 分解 能の低溥.

（2）ワインの酒質の多様化：ユニークな香気成分， リンゴ酸生成能，ペントース資化能などの付与，モノテ ルペン配樯体からのアグリコン遊離活性の増強（品種特 性の增強)

（3）製造工程の効率化：㠜集生，低泡性，亜硫酸酎 性, アルコール酎性，糖耐性，銅イオン耐性，マロラク チック発酵能などの付与, 発醭速度の增大.

また，育種手段としては，他の醇造用酵母の場合之同 様，自然界からの検索，分離，突然変異，接合による交 配，細胞融台 (プロトプラスト融合)、形質転换の5つの 方法が考えられる。 これらのらち，检索，分離の例とし ては，ワイン醉母(1)，野生キラー酔母(2)，キラーワイン

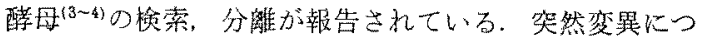
いて㛎，アルコール耐性 ${ }^{(5)}$ ，凝集性 ${ }^{(6)}$ ，硫化水素分泌能 の低下 ${ }^{(7)}$ ，低泡性 ${ }^{(8)}$ なとを目的とした育稙例が知られて いる他，濃縮果汁（マスト）から，マス卜特巽臭を有さ ないワインを跤成するアルコール酎性変異株 ${ }^{(2)}$ ，贵應口 イン酸造用の楉酎性変異株 ${ }^{10}$ などの実用化例も報告さ

Breeding of Excellent Wine Yeasts through Protoplast Fusion.

Kin-ichi SHimizu (Research Laboratory, Sainte Neige Wine Co.,Ltd., Yamanashi 405)
れている、接合を利用した育種は、ワイン醉母の大部分 がホモタリック株であるたかか，適用例としては，反複 戻し交配によるキラーワイン醳母の育秏(1)など数例し か報告されていない，形質転換を用いたワイン䣲母の育 種例としては，尊入した遺伝子の醭母内で発現には問 題が方ったものの, Lactobacillus delbrueckii のマロラ クチック発醅に関する遺伝子を導入した例(12)が知られ ている，細胞融合については，ワイン酵四関する限 り，Kar 1 変異株を利用したCytoduction によるキラー ワイン酵母造成(13-14)など数例が知られているにすぎ ない.しかしながら，ワイン酥母と Candida 属䙵母の 異栕間細胞融合株の取得(15)などの例にみられるよう な，育種梦料範曲の払大，電気細胞融合法の開発(16)， $P F G^{(17)}$, OFAGE ${ }^{(18)}$ なとのパルスフィールド勾配電気 泳動により，融合株の確認が容易になったことなどを考 え合わせると，細胞融合法は，形質転換法と並えで，今 娞のワイン醭母育種の重要な手段の一つと言元よう、本 稿ては，細胞融合法によるワイン酵母の育種について， 筆者らの奏用化例を紹介したい。

\section{1. ワイン酵母之清酒酵母の細胞融合株の造成 (19)}

本育種は，ブドウ由来のアロマに富み，かつフルーテ ィーなブーケを有するワインを酸成するワイン醭母造 成を目的として行った，図1に示した育種工程のごと く，まず，親株として，吟醇酒の䤑造に用いられ、ブー ケ生産性に瞹れた清酒䤃母 S. cerevisiae 協会 9 号 (hol ho 2 倍体)，ならびに，ブドウのアロマ成分 (主として モノテルペン類）に富んだワインを醇成するワイン酵母 S. cerevisiae ガイゼンハイム 74 株のへテロタリック 2 倍体株 (ho/ho，KHS キラー) を選択 し，招の搞のの $\alpha$ 接合型半数体の，呼吸欠損性 $\left(\rho^{0}\right)$ でから栄養要求性 の変異株同志で，PEG 存在下゙でプロトプラスト融合を 行い，融合株を最少寒天培地中で選択的に再生させた後， 增殖がとくに良好で，KHSキラー性を有する10株を選 出した.これら10株について，継代培着後のPFGによ 


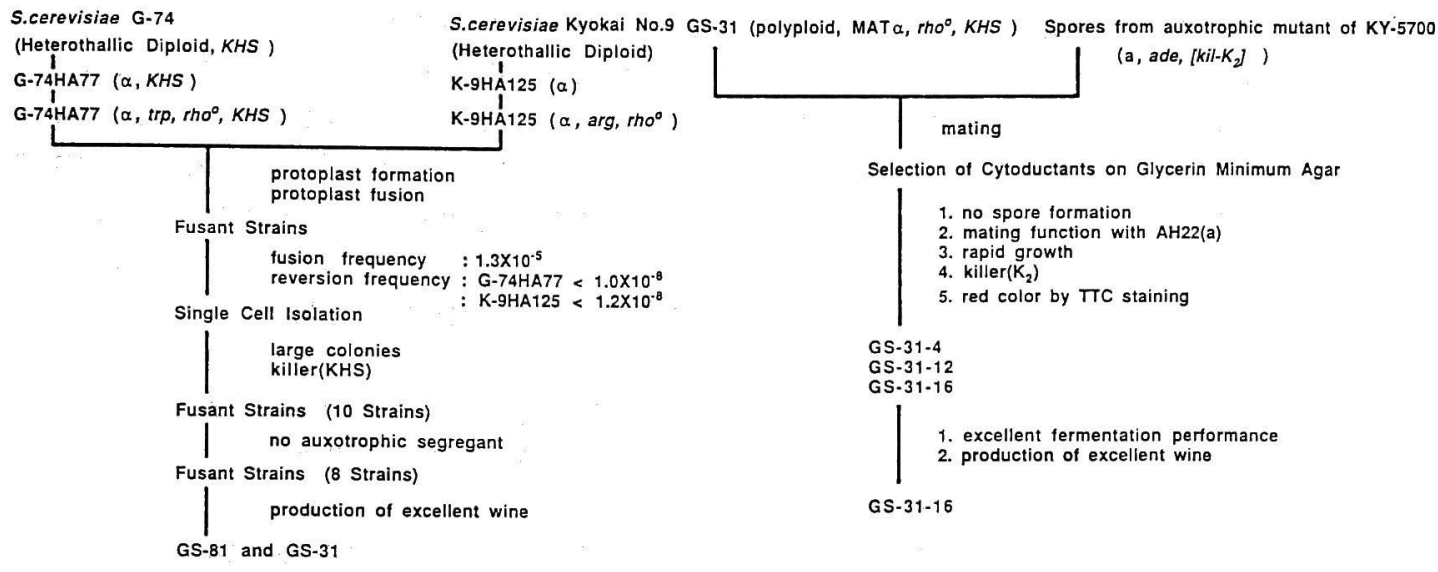

図 1 ワイン酵母と清酒酵母の細胞融合株の育種工程

る染色体パターンの变化, 栄着要求性や非キラー性コロ ニーの出現を指標として, 遗伝的に安定な融合株 8 株を 選抜し，おの打のにつて, ワインの小仕込試験を繰り 返し，良質のワインを醕成する GS-31，GS-81 の2株を 得た。これら 2 株は， $\alpha$ 接合型を有し，呼吸欠損性であ った. また, GS-81 は 2 倍体, GS-31 は 3 倍体に相当す る DNA 含量を有していたことから, GS-81, GS-31 は それぞれ， $\alpha / \alpha 2$ 倍体， $\alpha / \alpha / \alpha 3$ 倍体と推定された.

一方, 筆者らは, 諸外国から収集したワイン酵母のミ トコンドリア DNA の制限酵素による切断パターンが 異なることを見出し，ミトコンドリアがワイン酵母の醸 造特性, 製成ワインの酒質に及ぼす影響について, $\rho^{0}$ 変 異株とした後, 他株のミトコンドリアを cytoduction し て得た cytoductant 間の比較によって検討を行ってい るが, この研究の過程で, ワイン酵母 S. cerevisiae KY5700 株 ( $\mathrm{HO} / \mathrm{HO} 2$ 倍体, $\mathrm{K}_{2}$ キラー) 由来のミトュン ドリアを導入された株は, 概して, 発酵速度, 低温発酵 性，製成ワインの品質の点で，優れている傾向があるこ とを見出した.

そこで, 育種工程の第 2 段階として，KY-5700 株のミ トコンドリアを， 2 株の融合株中ブーケ生産性のより優 れた GS-31 へ, cytoduction することとした. 方法は, KY-5700 株のアデニン要求性変異株から取得した胞子 と GS-31 の間の, spore-to-cell mating によって行っ た.グリセリン最少培地上で選抜された接合株のなかか ら， $\alpha$ 接合型を示し，胞子形成能を有さず， $\mathrm{K}_{2} \neq$ キー性 を示し, 増殖の良好な株を選出した後, PFGを行って, GS-31 と同様な染色体パターンを有する 3 株を選び出し
た. これら 3 株の cytoductant について, ワインの小仕 込試験による比較を行い, 醸造特性, 製成ワインの品質 共に優れた GS-31-16 株を選出した.

GS-31-16 は, GS-31 と同様, 3 倍体に相当する DNA 含量を有し, S. cerevisiae AH-22 (a) との接合株の形成 する 4 胞子の接合型が $\mathrm{a}: \alpha:$ non-mater $=0: 2: 2$ に分 離することから， $\alpha / \alpha / \alpha 3$ 倍体と推定された. また， PFG による検討結果から, 協会 9 号, ガイゼンハイム

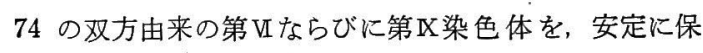
持していることが判明した（図 2 ). さらには，本株が KY -5700 株由来のミトコンドリアを有することも， ミ

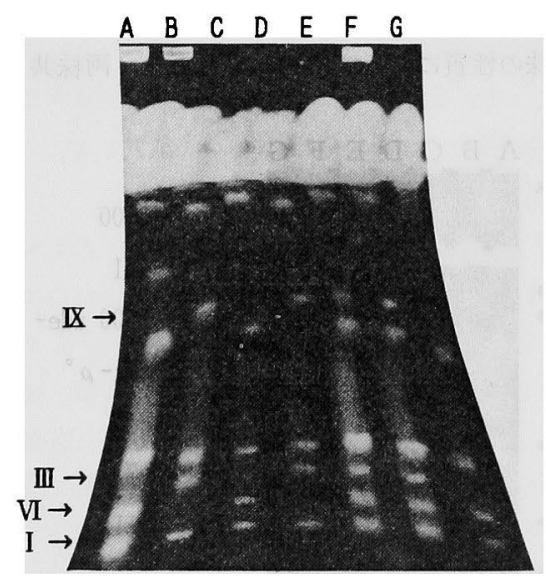

Electrophoresis was carried out in a $1 \%$ agarose, TBE buffer gel at $330 \mathrm{~V}$ for $55 \mathrm{hr}$ (pulse time: $50 \mathrm{sec}$ ).

A, G-74; B, Kyokai No. 9; C, G-74HA77; D, K-9HA125; E, GS-31; F, GS-31-16; G, KY-5700.

図 2 親株, 融合株の染色体パターンの比較 
トコンドリア DNA の, Bam HI, Eco RI による切断パ ターンの比較により明らかになった。

GS-31-16 は, 低温発酵性に優れ，その醸成する白ワイ ンは，化学的には，極度に低い酢酸含量と比較的低いコ ハク酸含量を特徽とし，官能的には，当初の目的どお り，豊かなアロマとほのかな吟䁔酒様プーケを有し， イトタイプな味を特徵とする優れたワインであった.

2. シャンパン酵母とワイン酵母の細胞融合株の造 成 $(20)$

使用するワイン酵母による酒質の多様化を目的とした 育種に関して，も51つ別の例を，簡単に紹介する.

親株として，ビン内発酵中のシャンパンより分離し 良好な低温発酵性, 強いアルコール耐性, 低い酢酸生成 量を特徵とするシャンパン醉母 C. cerevisiae（旧分類で はS.bayanus) SW-861 (HO/ho 2 倍体, $\mathrm{K}_{2}$ キラー), な らびに，良質のワインを醸成し，前述のごとく“優良”な ミトコンドリアを保持しているワイン醅母 S. cerevisiae $\mathrm{KY}-5700$ ( $\mathrm{HO} / \mathrm{HO} 2$ 倍体, $\mathrm{K}_{2}$ キラー) を選び, SW8612 倍体の $\rho^{0}$ 变異株と KY-57002 倍体のアデニン要 求性変異株の間でプロトプラスト融合を行い, グリセリ ン最少寒天培地中で融合株の選択再生を行った．得られ た融合株のなかから，低温での増殖が良好で，栄養要求 性の segregant を生じない 3 株を選出し、ワインの小 仕込試験によって評価したところ，SWW-12 が白ワイ ン用, SWR-7 が赤ワイン用酵母として優れていること が判明した.

これら 2 株の性質について検討したところ，両株共 2

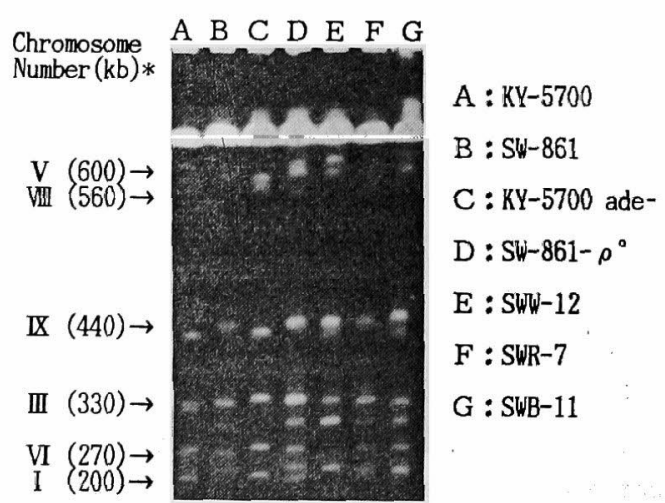

* S. cerevisiae Yeast Chromosomal DNA PFE-Certified Standard (Beckman Instruments, Inc.)

Electrophoresis was carried out in a $1 \%$ agarose,

TBE buffer gel at $170 \mathrm{~V}$ for $40 \mathrm{hr}$ (pulse time:50 sec).

図 3 親株, “融合株の染色体パターンの此較
倍体と注ぼ同程度の DNA 含量を有し，かつ胞子形成能 を有すること，SWW-12 は L 特よび M-dsRNA プラ スミドを保持しているが，SWR-7 では M-dsRNA プ ラスミドが欠失していること，いずれの株も SW-861 同 様，ガラクトース資化性を有さないことなどが明らかに なったまた，PFG による検討の結果（図 3)，SW 861 とW-861 $\rho^{0}$ では第 I と第 Vが，KY-5700 では 第正染色体が 2 種類認められること, KY -5700 ade は 1 種類の第正染色体しか有さないこと，融合株 SWW-12 は， 1 種類の第 VI，第 I 染色体のみを有し，両親株由来 の第X染色体を安定に保持していること（第X染色体に 関して trisomy と考兄らる)，SWR-7・は，第 I 染色 体を 1 種類 しか保持していないことを除けぱ，SW-861 と同様な染色体パターンを有していることなどが判明し た. 両融合株が，KY-5700 由来のミトコンドリアを安 定に保持していることも，連続的継代培養後の両株のミ トコンドリア DNA の, 制限酵素切断パターンから確 認された

ワイン酵母とてての特性に関しては, SWW-12 は，低 温発酵性, アルコール生成能にきわめて優れ, コハク 酸，酢酸含量の低い，軽くフルーティーな白ワインを醉 成し, SWR-7 は, 赤ワインモロミ中での発酵速度は両 親株とほぼ同等であるが，アロマ、ブーケに富み，渋味 の比較的少ない赤ワインを醇成した。

おわりに

以上，細胞融合によるワイン酵母の育種例の一端を紹 介したが，親株に何らかの標識が必要であること，形質 転換の場合と異なり，特定の形質のみを選択的に導入す ることが困難であることなどの，細胞融合法の欠点を明 確に認識して，親株の標識なしに融合株を選別したり， 目的の性質のみを有する融合株を選出する方法、さらに そのなかから，実用化可能な株を効率的に選び出すプレ スクリーニング系などの開発に目を向けて行く姿勢が, ワイン酵母に限らず，一般に，醕造用あるいは虐業用䣲 母を育種，実用化してゆくら壳で，きわめて重要である う.

（1）戸塚 昭, 北野一好, 風間茂美：昭和 61 年度 ASEV JAPAN 講演要旨集, 1986, p. 15.

(2) K. Kitano, M. Sato, T. Shimazaki and S. Hara : J. Ferment. Technol,, 62, 1 (1984).

(3) K. Shimizu, T. Adachi, K. Kitano, T. Shimazaki, A. Totsuka, S. Hara and H. H. Dittrich:J. Ferment. Technol., 63, 421 
(1985).

(4) K.Shimizu, T.Adachi, K. Kitano, T. Shimazaki, A. Totsuka, S. Hara and H. H. Dittrich : Wein-Wiss., 40, 258 (1985).

(5) S. I. Alikhanyan, G. M. Nalbandyan and B.P. Avakyan: Genetika, 7, 1287 (1971).

(6) S.I. Alikhanyan, G. M. Nalbandyan and B. P. Avakyan: Genetika, 7, 1452 (1971).

(7) P. Tauro and O.P. Rupela: VI Int. Ferm. Symp./V Int. Symp. Yeast, London (Canada) (1980)

(8) R. Eschenbruch and J.M. Russell : Vitis, 14, 43 (1975).

（9）原武，足立哲夫，広瀬 泉，清水健一，秋 山裕一：昭和 60 年度発酵工学会大会講演要旨 集, 1985, p.38.

（10）的清水健一，原武，三井徽也，横森洋一，足 立哲夫，秋山裕一：昭和 60 年度発酵工学会大 会講演要旨集, 1985, p. 53.

(11) S. Hara, Y. Timura and K. Otsuka: Am. $J$. Enal. Vitic., 31, 28 (1980).
(12) S. A. Williams, R. A. Hodges, T.L.Strike, R. Snow and R. E. Kunkee: Appl. Environ. Microbiol, 47, 288 (1984).

(13) T. Seki, E. H. Choi and D. Ryu: Appl. Environ. Microbiol., 49, 1211 (1985).

（14）風間茂美，北野一好，戸埭 昭：昭和 62 年度 日本農芸化学会大会鹪演要旨集, 1987, p. 133.

（15）横样一，秋山裕一，清水健一：昭和 62 年度 日本農芸化学会大会譿演要旨集, 1987, p. 131 .

(16) H. J. Halfmann, C.C. Emeis and U. Zimmermann: FEMS Microbial. Lett., 20, 13 (1983).

(17) D. C. Schwartz and C. R. Cantor: Cell, 37, 67 (1984).

(18) G.F.Carle and M. V. Olson: Nuc. Acids Res., 12, 5647 (1984).

(19) Y. Yokomori, H. Akiyama and K. Shimizu : Yeast, 5 (special issue) April, 145 (1989).

（20）横湘洋一，秋山裕一，清水健一：1989 年度日 本農芸化学会大会講演要旨集, 1989, p.117. 